\title{
Influence of Lamina Wood on the Physical Properties, the Nature of Mechanics, the Strong Class on the Combination of Sengon Wood and Merbau Wood
}

\author{
Joko Suryono $^{1, *}$ Yudi Pranoto $^{1}$ \\ ${ }^{1}$ Civil Engineering Department of Samarinda State Polytechnic - Indonesia \\ ${ }^{*}$ Corresponding author. Email: jokosuryono@polnes.ac.id
}

\begin{abstract}
Wood is a material used by man to meet his life needs, both as building materials and other tools. Conditions as a construction component require large size, one that can be by making lamina wood. This study is the influence of lamina on physical properties, mechanical properties, healthy classes using MUF adhesives, which can provide knowledge, so it is utilized as an alternative to solid wood. Deutsches Institut for Normung Standard (DIN) 52186. The value of lamina wood content is between $21.19 \%$ to $12.43 \%$, density value between $0.58 \mathrm{~g} / \mathrm{cm} 3$ to $0.73 \mathrm{~g} / \mathrm{cm} 3$, lamina wood shear strength between $3.1 \mathrm{~N} / \mathrm{cm} 2$ to $6.4 \mathrm{~N} / \mathrm{cm} 2$, MOE between $6192 \mathrm{~N} / \mathrm{cm} 2$ to $13275 \mathrm{~N} / \mathrm{cm} 2$, MOR between $51 \mathrm{~N} / \mathrm{cm} 2$ to 85 $\mathrm{N} / \mathrm{cm} 2$. Diversity analysis shows that the combination of wood type factor (A) and layer count factor (B) significantly affects MOE diversity analysis of 100.93 very significant and 16.77 very significant. For (MOR) significant influences of 5.66 significant and 7.07 significant. In contrast, adhesive and shear strength significantly affect diversity analysis of 11.71 very significant and 9.03 very significant. Merbau wood as face/back and Sengon wood as core (layer 3 and 5) can be classified as strong grade II-III. For Modulus Of Rupture (MOR) on the treatment of Sengon wood as face/back and Merbau wood as core (3 and 5) as well as Merbau wood as face/end and Sengon wood as meat (3 and 5) can be classified into strong grades II-III.
\end{abstract}

Keywords: Lamina Wood, Physical Properties, Mechanics, Strong Class

\section{INTRODUCTION}

Wood is one of the materials used to meet needs, either as construction materials or other material aids. The use of wood as a construction material has been known for a long time, not only for the construction of roofs, construction of four open dits, in water, or on the ground on the ground. The need for wood increases as the population grows, both logs and further processing, so enough wood is needed to meet the requirements.

Deforestation is getting worse diluting carbon sources, damaging the environment, and making timber supplies meet construction needs less. One of the efforts to reduce the dependence on wood supply from forests is from Industrial Forest Plants. The type of tree that is generally planted in industrial Plant Forest is a fastgrowing plant, medium diameter wood with low density. On the other hand, the need as a structural component requires considerable dimensions; therefore, a method is needed that meets the requirements. One of the efforts that can be done is by making lamina wood, and lamina wood can utilize several types of wood with a small diameter to small size. Judging by the day of making lamina wood, then the advantage of lamina wood is to obtain the desired dimension size of wood and free from

that have a greater density. So in the study used a combination of two different wood Jens namely Sengon wood with Merbau wood. In cold pumping systems, adhesives scattered on each surface of lamina wood are pressed with clamps to an absolute pressure for more than 24 hours under constant temperatures, according to $\mathrm{K}$. Kim's research, S. Km, S. Yang et al. [6].

This study is lamina on physical properties, mechanical properties, substantial value using Melamine Urea Formaldehyde adhesive. They are expected to provide knowledge so that it is utilized as a reliable wood alternative. 


\section{METHOD}

\subsection{Research Sites}

The research was conducted in the wood Engineering and Testing Laboratory of the Faculty of Forestry, Mulawarman University.

\subsection{Tools and Materials}
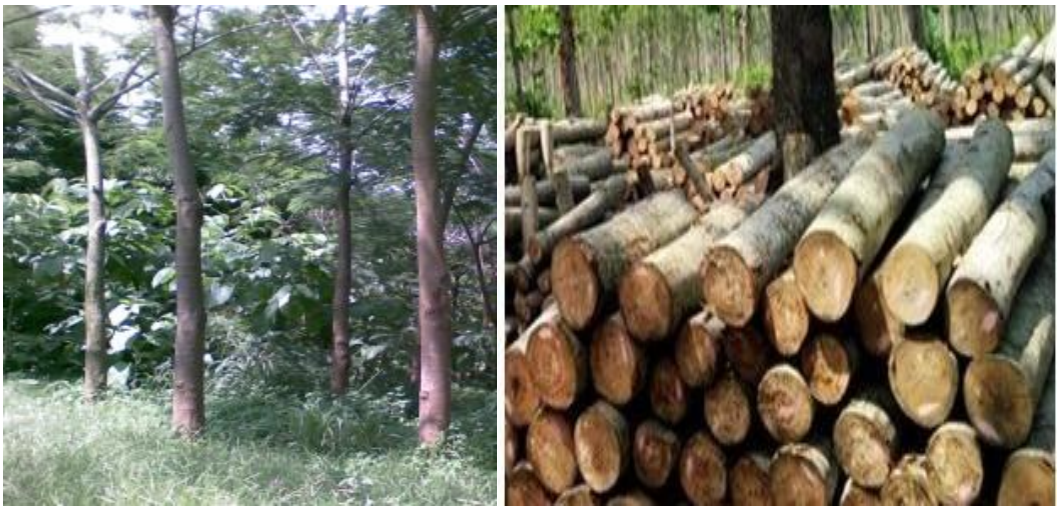

Figure 1 Sengon wood

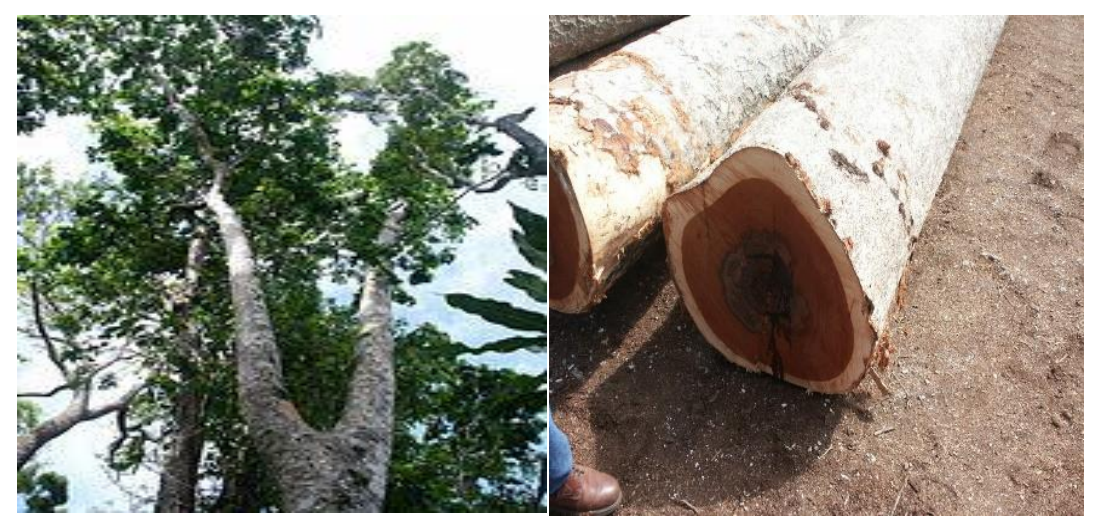

Figure 2 Merbau wood

\subsection{Procedure}

The round wood material is cut into beams with $6 \mathrm{~cm}$ x $6 \mathrm{~cm} \mathrm{x} 90 \mathrm{~cm}$ into several rods inserted in the furnace. Dry water content is created, object test according to Deutsches institute for norming (DIN) equipment standard 52186, where static bending strength test object size is made for each solid $2 \mathrm{~cm} \times 2 \mathrm{~cm} \times 36 \mathrm{~cm}$ Figure 3 , three layers $0.7 \mathrm{~cm} ; 0.65 \mathrm{~cm} ; 07 \mathrm{~cm}$ (each layer $0.7 ; 0,65 ; 0.7 \mathrm{~cm} \times 2 \mathrm{~cm} \times 36 \mathrm{~cm}$ ) Figure 4, Figure 5. I contrast while the material size thickness of the static
Tools used for testing are measuring instruments (micrometers), scales (electric balance), oven caliper, constant room, testing machine (universal Testing Machine $100 \mathrm{kN}$ with type Otto Wollpert 10 Tuz 745, pendulum type Wollpert PW 15 S.The materials used in the study are Sengon Wood Figure 1, Merbau Wood Figure 2, Melamine Adhesive Urea Formaldehyde (MUF). 


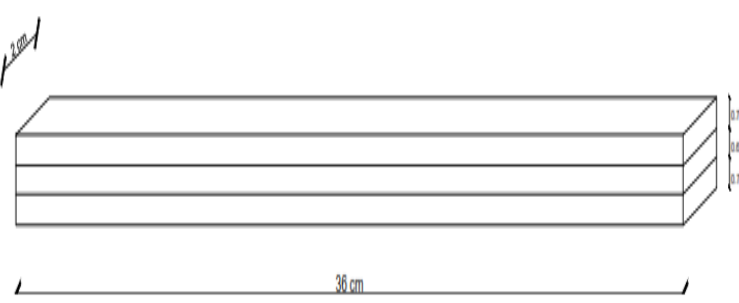

Figure 3 Solid sengon, Merbau

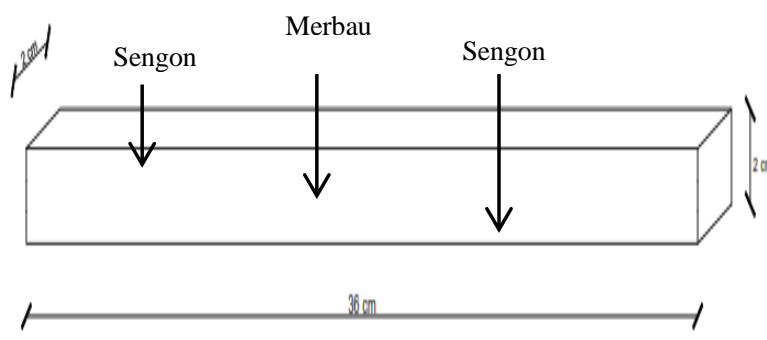

Figure 4 Layer sengon-merbau-sengon

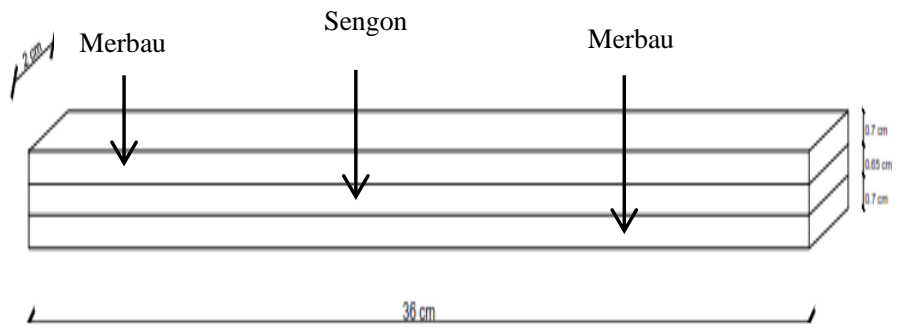

Figure 5 Layer merbau-sengon-merbau

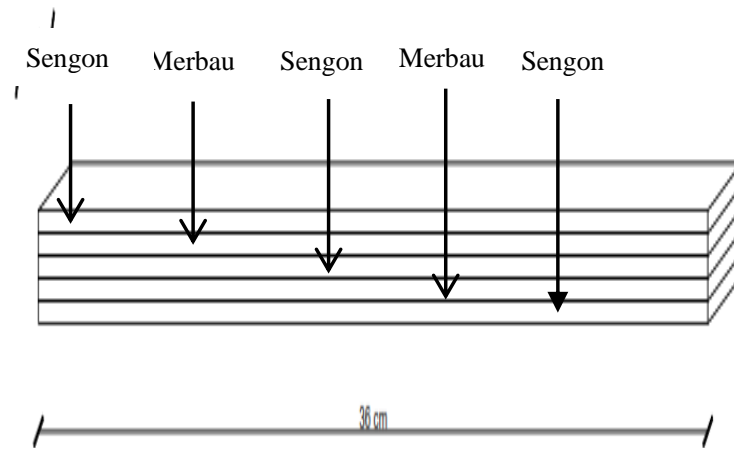

Figure 6 Layer sengon-merbau-sengon-merbau-sengon

\subsection{Data Analysis}

The data generated from the test is then arranged in a data matrix, and-analysis using a randomized factorial test complete with two factors.

Factor A type of wood coating.

a1 $=$ Sengon wood

a2 = Merbau wood

Factor B number of wood layers

b1 = three layers

b2 = five layers Formula used (Stel and Torrie, 1991)

$Y i j k=\mu+\alpha i+\beta j+(\alpha \beta) i j+\varepsilon i j k$

Where :

Yijk = observation factor value

$\mu \quad=$ general average of population (middle value)

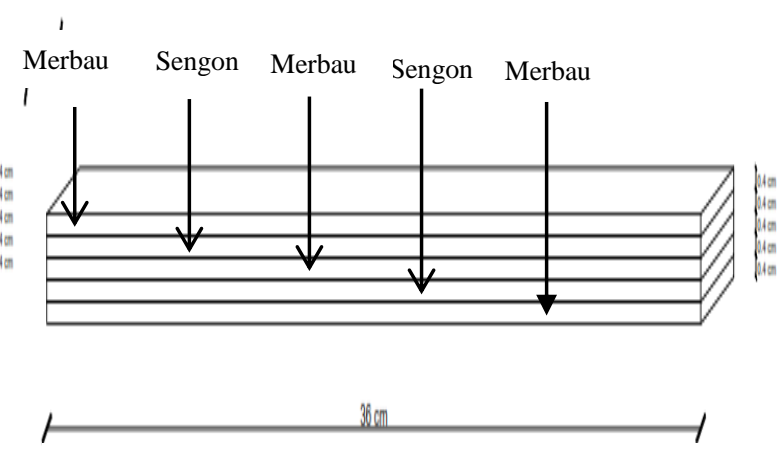

Figure 7 Layer merbau-sengon-merbau-sengon-merbau

$\alpha \mathrm{i}=$ influence of wood type Faktor layer

$\beta \mathrm{j} \quad=$ influence factor of the same layer

$(\alpha \beta)$ ij = influence of interaction between wood types and number of layers

cijk = testing error

Layer combination :

a1b1 = layer Sengon - Merbau - Sengon

a1b2 = layer Sengon - Merbau - Sengon - Merbau Sengon

a2b1 = layer Merbau - Sengon - Merbau

a2b2 = layer Merbau - Sengon - Merbau - Sengon Merbau

A $=$ Combination factor

B = Layer count factor 
$\mathrm{AB}=$ Interaction of combination factors with the number of layers

\section{RESULT AND DISCUSSION}

\subsection{Physical properties of wood}

\subsubsection{Moisture content}

Testing the physical properties of lamina wood layer Sengon wood and Merbau wood can be seen in Figure 9. The product of A.Lestari, Y. Hadi, D. Hermawan et al. [1] lamina was dried naturally and then dried with a water content of about $12 \%$, for three and five-layer combinations obtained $12.19 \%$ to $12.43 \%$ with an average value of $12.39 \%$, indicating test objects in conditions worth testing after being placed in constant space.

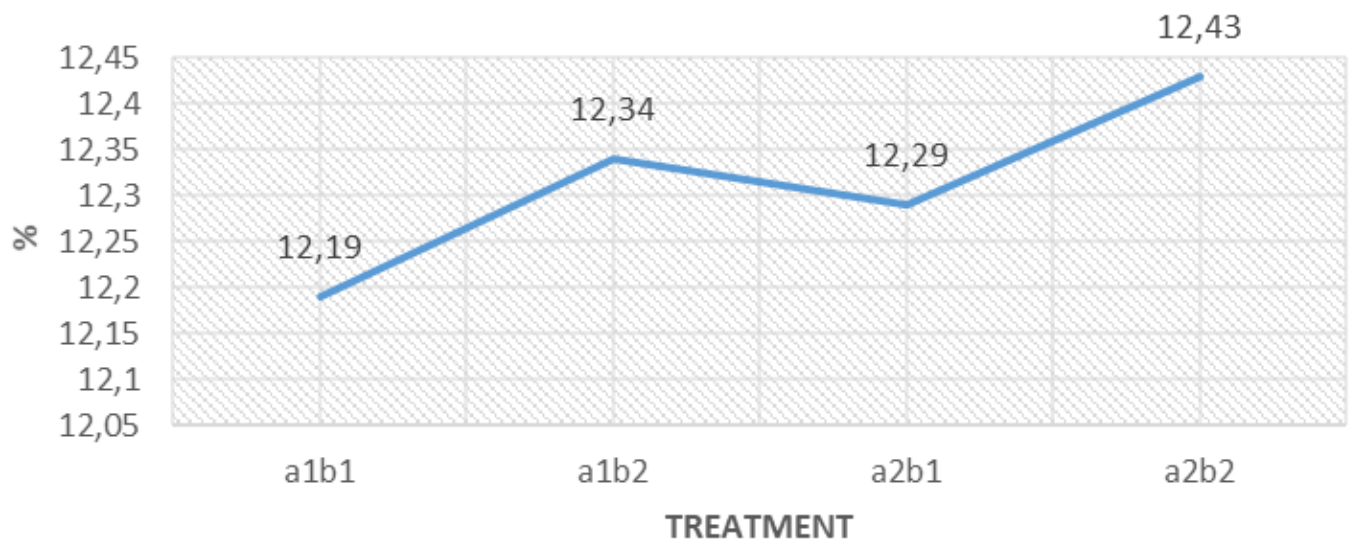

Figure 8 Moisture content

\subsubsection{Density}

Testing the density of lamina wood layer Sengon wood and Merbau wood can be seen in Figure 10. For three and five-layer combinations obtained $0.58 \mathrm{~g} / \mathrm{cm} 3$ to $0,73 \mathrm{~g} / \mathrm{m} 3$ with an average value of $0.67 \mathrm{~g} / \mathrm{cm} 3$, indicating test objects in conditions worth testing after being placed in constant space.

The average density value also increases as the number of layers increases. Five-layer lamina wood has a more excellent density value than three-layer lamina wood with the same upper bottom wood material. Because the number of more layers will make the mass of lamina wood increase, but the volume of lamina wood remains as strange as making the density of timber increase.

The analysis of the diversity of the influence of the number of layers is very significant on the density of lamina wood produced because the number of different layers results in different density values. The more the number of layers, will increase the density value compared to the fewer layers. The results also stated a difference in density value caused by differences in the number of layers in lamina wood.

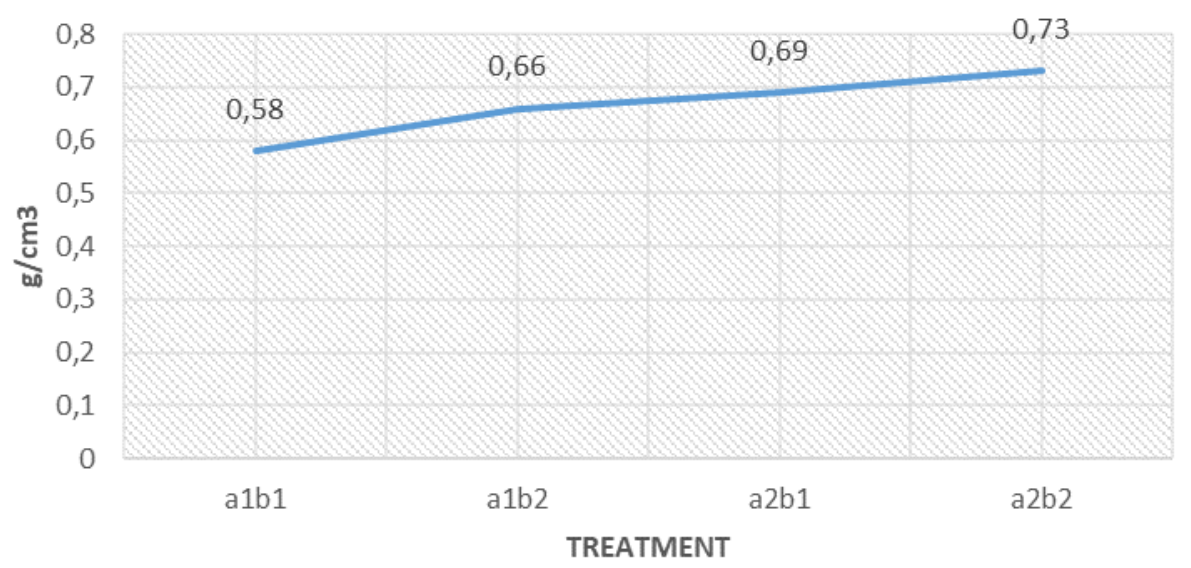

Figure 9 Density 


\subsection{Properties of Wood Mechanics}

\subsubsection{Shearing Power}

Testing the shearing of lamina wood layer Sengon wood with three-layer value $4.6 \mathrm{~N} / \mathrm{cm} 2$, Sengon wood with Sengon wood value $3.1 \mathrm{~N} / \mathrm{cm} 2$, three-layer with three-layer value $6.4 \mathrm{~N} / \mathrm{cm} 2$ can be seen in Figure 10.

The sliding strength test Figure 10 shows that the shear strength of the lamina wood combination of Sengon wood with Merbau wood compared to solid wood shear firmness does not get an increase in power even tends to be lower value.

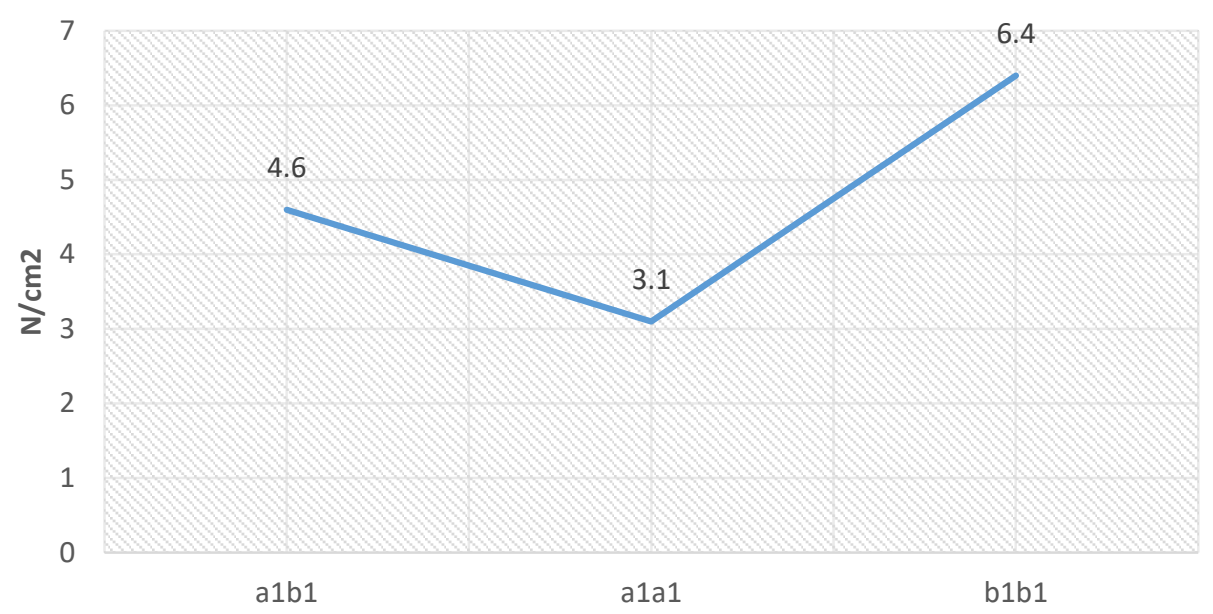

Figure 10 Shearing power

Judging by the average strength of the value of the a1a1 treatment, the lowest average weight, this is due to the arrangement of Sengon wood type with Sengon wood, compared to the treatment of a1b1 between Sengon wood and Merbau rattan wood higher than a1a1. The treatment of b1b1 is the highest average value due to Merbau wood - Merbau wood that has a high density.
Figure 11 shows the flattening value of wood damage, indicates a relationship with the paste's strength. The higher the amount of wood damage than the better the power of the paste. Because of the increasingly damaged wood tested, this proves that the adhesion bond between adhesive and wood is firmly connected. From the diversity analysis with a 9.03 significant value, the treatment has significant effects on wood damage.

\subsubsection{Wood Damage}

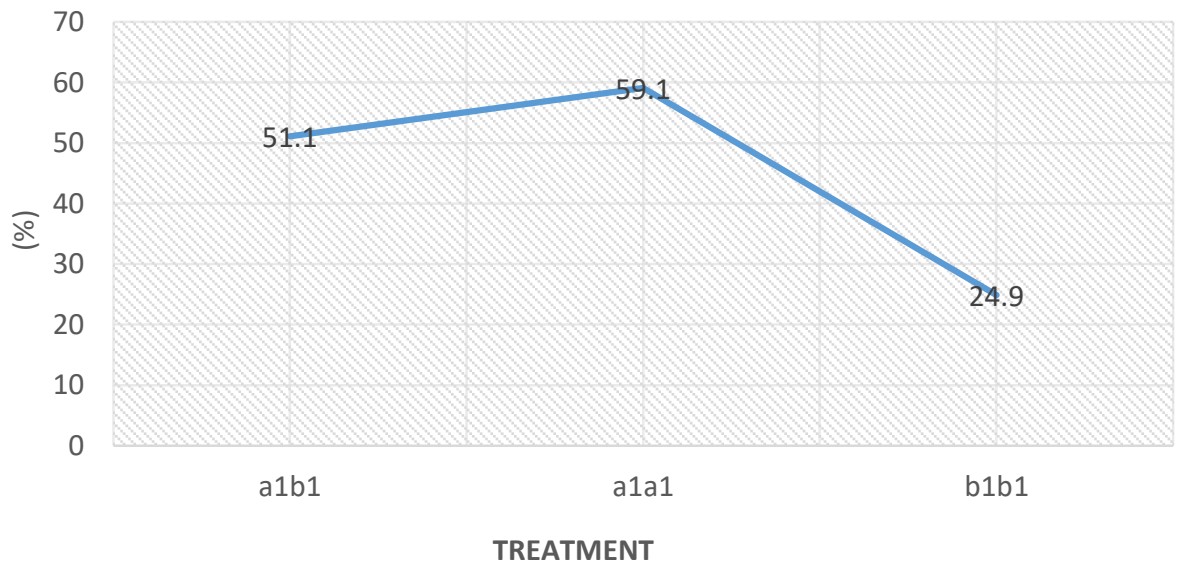

Figure 11 Damage

\subsection{Modulus Of Elasticity (MOE)}

Figure 12 below shows that the highest level is found in the treatment a2b2 with a value of $13275 \mathrm{~N} / \mathrm{mm} 2$ and the lowest Modulus Of Elasticity is 6192 N/mm2. Three- layer lamina wood (a1b1) with an amount of 6192 $\mathrm{N} / \mathrm{mm} 2$ and five layers (a1b2) with test results a Sengon wood back face compared to solid Sengon wood of 8622 $\mathrm{N} / \mathrm{mm} 2$ the average elasticity value is smaller than solid Sengon wood. 


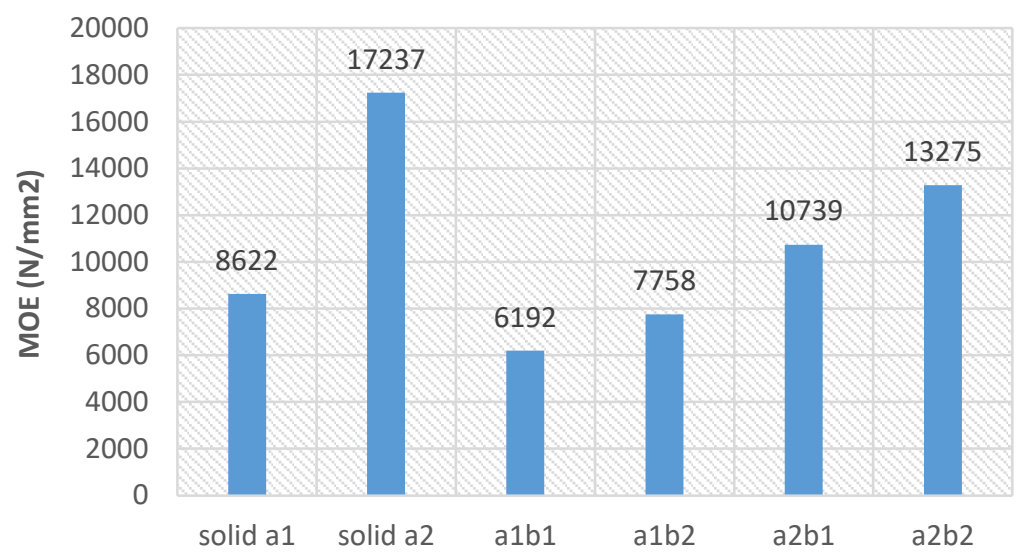

\section{Figure $12 \mathrm{MOE}$}

While the lamina wood combination of Merbau wood, test results compared to solid timber Merbau wood amounted to $17237 \mathrm{~N} / \mathrm{mm} 2$, the value of static bending strength produced is also smaller. This refer occurs due to differences in timber moistened adhesives, penetration of bonds, and density of both Sengon wood and different Merbau wood. Sengon wood with a low density has larger pores; in adhesive penetration adhesive, many go into the pores smaller Sengon wood than Merbau wood with smaller pores the glue that anchors make the bonding not maximal.

The combination of wood types exerts a very significant influence on the value of MOE. Because in the treatment of $\mathrm{a} 2 \mathrm{~b} 2$, the more dominant layer Merbau wood, as Merbau wood affects the lamina wood. While in the treatment of a1b1 layer, the more dominant is Sengon wood das not effect on lamina wood.

Merbau wood diversity has a higher density than Sengon wood, so Merbau wood affects the value of Modulus Of Elasticity (MOE). This density affects the amount of modulus of elasticity. Based on the research of R. Komariah, Y. Hadi, M.Massijaya et al. [8] because higher density wood has a higher MOE, and Merbau wood density is higher than Sengon wood. Besides, all glulam wood, except for five-layer wood glulam, has a higher MOE value. If combined with other glulam, indicating that wood, which has the highest wood density, plays a role in achieving higher MOE.

The treatment of the number of layers the study results was carried out to significantly influence, From the results of testing Modulus Of Elasticity (MOE) that moe level values on a1b1 and a1b2 treatment can be classified class IV -V. While in the treatment, $\mathrm{a} 2 \mathrm{~b} 1$ and a2b2 can be classified into grades II-III.

\subsection{Modulus Of Rupture (MOR)}

Figure 13, compared to the Sengon wood value of $67.5 \mathrm{~N} / \mathrm{mm} 2$, the a1b1 treatment is $51 \mathrm{~N} / \mathrm{mm} 2$ no larger than solid Sengon wood, and the a1b2 treatment is 73 $\mathrm{N} / \mathrm{mm} 2$ larger than solid Sengon wood. While solid wood Merbau of $78.6 \mathrm{~N} / \mathrm{mm} 2$ on a $2 \mathrm{~b} 1$ treatment is $71 \mathrm{~N} / \mathrm{mm} 2$ no bigger than solid Merbau wood and a2b2 treatment is $85 \mathrm{~N} / \mathrm{mm} 2$ larger than solid Merbau wood.

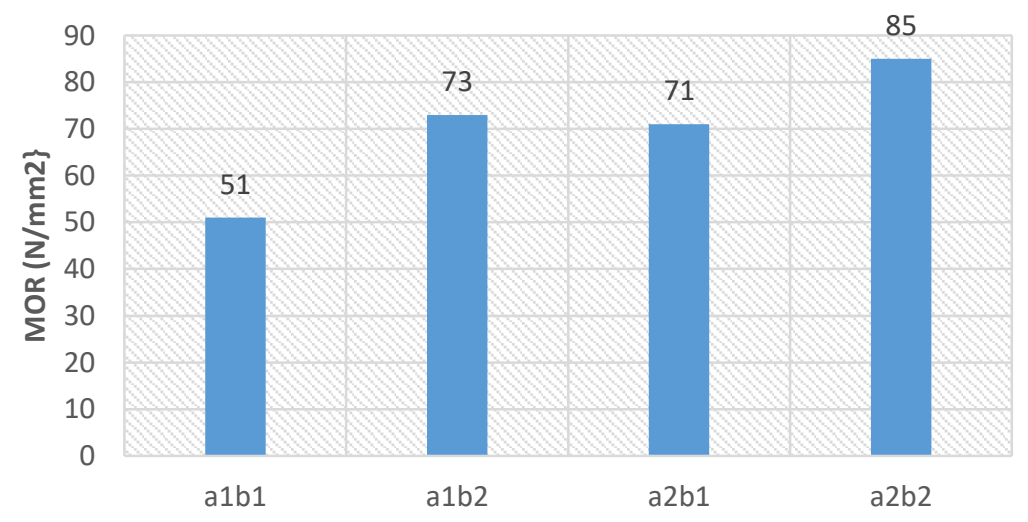

\section{Figure 13 MOR}

In figure 13 it can also be seen that the treatment of the number of layers shows a significant influence on the collapsing force (MOR). This was at the time of testing of broken power (MOR) there was an increase in the number of layers in line with the research of Iskandar and Supriyadi [5] and Widiati [9]. 
The diversity analysis of factor A value of 5.66 significant and a factor B value of 7.07 significantly influences MOR. In contrast, while the ab factor value (interaction) of 0.40 no significant provides insignificant results. As with modulus of elasticity (MOE) of 0.94 no significant, the amount of Modulus Of Rupture (MOR) of lamina wood from the combination of Sengon wood with Merbau also has factors two different types of wood in lamina wood. Where Sengon wood is face/back and Merbau wood is the core so that there is an increase in the value of Modulus Of Rupture (MOR). From the diversity analysis, the number of layers shows a significant influence on modulus rupture (MOR).

The same is said when Modulus of elasticity (MOE) testing increases with an increasing number of layers. The number of layers has a significant effect on MOE and MOR, suggesting the number of layers has a significant impact on water content, density, MOR, and MOR.

\section{CONCLUSION}

The water content of lamina wood is between $21.19 \%$ to $12.43 \%$, and the density value is between $0.58 \mathrm{~g} / \mathrm{cm} 3$ to $0.73 \mathrm{~g} / \mathrm{cm} 3$. Mechanical properties of lamina wood shear strength value between $3.1 \mathrm{~N} / \mathrm{cm} 2$ to $6.4 \mathrm{~N} / \mathrm{cm} 2$, Damage between $24.91 \%$ to $59.07 \%$, MOE between $6192 \mathrm{~N} / \mathrm{mm} 2$ to $13275 \mathrm{~N} / \mathrm{mm} 2$, MOR between 51 $\mathrm{N} / \mathrm{mm} 2$ to $85 \mathrm{~N} / \mathrm{mm} 2$. Based on the results of the diversity analysis shows that the combination of wood type factor (A) and layer count factor (B) has a very significant effect for Modulus of Elasticity (MOE), resulting from a diversity analysis of 100.93 very significant and 16.77 very significant. For Modulus Of Reptur (MOR), it has substantial influences of 5.66 significant and 7.07 significant. In contrast, wood shear strength between the adhesive and wood significantly affects a diversity analysis of 11.71 very significant and 9.03 very significant. From the test results, Modulus Of Elasticity (MOE) can be seen as the value of the level on the treatment of Sengon face/back, and Merbau as cores (layers 3 and 5) can be classified into strong grades IVV. In contrast, Merbau as face/ end and Sengon as bodies (layers 3 and 5) can be classified as strong grades II-III. For Modulus Of Rupture (MOR) on Sengon treatment as face/back and Merbau as core (layer 3 and 5) and Merbau as face/back and Sengon as core (layers 3 and 5) can be classified into strong grades II-III.

\section{REFERENCES}

[1] A.Lestari, Y. Hadi, D. Hermawan, et al., 2015. Glulam Properties of Fast-growing Species Using
Mahogany Tannin Adhesive. Journal BioResources, Vol. 10 (4), page 7419-7433

[2] J. David Barrett, J. Lee, J. OH et al, Yield analysis of Hem-Fir (N) lamina for Japanese visual and machine grade standards, 2014. Journal of Wood Science, Vol. 60 (6), 389-395

[3] G. Jeong, J. Lee, H. Yeo, et al. 2013, Optimized Lamina Size Maximizing Yield for Cross-Laminated Timber Using Domestic trees. Journal of the Korean Wood Science and Technology, vol. 41 (2), page 141 $-148$

[4] G. Sozbir, I. Bektas, A. Kilic, Ak., 2019. Influence Of Heat Treatment And Intensification on Mechanical Properties of Polar Wood, Journal Maderas: Tienda Y Tehnlogia, Vo. 21 (3), page 481 492

[5] Iskandar, M.I. dan A. Supriadi, 2017. Pengaruh Jenis Kayu dan Jumlah Lapisan Terhadap Sifat Venir Lamina. Jurnal Ilmu Pertanian Indonesia (JIPI), Vol. 22 (1), Hal, $34-40$

[6] K. Kim, S. Km, S. Yang, et al., 2015. Bonding Performance of Adhesives with Lamina in Structural Glulam Manufactured by High-Frequency Heating System, Journal of the Korean Wood Science and Technology, Vol. 43 (5), page 682 - 690

[7] M. Roohnia, A. Hemmasi, A. Yavari, et al. 2014, Modulus of Elasticity in Scarf-jointed Wooden Beams: a Case Study with Polyvinyl Acetate and Isocyanate Adhesive. Journal of Wood ScienceVol. 60 (5), page $321-326$

[8] R. Komariah, Y. Hadi, M. Massijaya et al. (2015). Physical - Mechanical Properties of Glued Laminated Timber Made From Tropical Smalldiameter Logs Grown in Indonesia, Journal of The Korean Wood Science and Technology, Vol. 43 (2), page 156-167

[9] Widiati, K. Y., 2016. Sifat Fisika dan Mekanika Laminasi Dari Kombinasi Bambu Betung (Dendrocalamus asper) dan Meranti Kuning (Shorea $\mathrm{sp).}$

http://respository,unmul.ac.idupload/jurnal/file_150 76119957,pdf.Diakses 18 Oktober 2018

[10] Widia YK, Supraptomo B, Budi A, 2018. Karakteristik Sifat Fisika Kayu Lamina Kombinasi Jenis Kayu Sengon Dan Jenis Kayu Merbau. Journal Ulin Hut Trop, Vol. 2(2), page 93-97 